\title{
The Paradigmatic Mendel at the Sesquicentennial of "Versuche über Pflantzen-Hybriden": Introduction to the Thematic Issue
}

\author{
Erik L. Peterson · Kostas Kampourakis
}

Published online: 26 August 2014

(C) Springer Science+Business Media Dordrecht 2014

\section{Mendel, Mendelism and the Distortion of History}

Open a standard biology textbook and one will likely find two historical figures prominently displayed among pages full of contemporary biological information. The first is Charles Darwin (1809-1882), often portrayed as a wizened, grandfatherly figure with a flowing white beard dressed in somber Victorian garb. The second figure is younger, bespectacled, and donning garments appropriate for a member of some Christian order. Often he is standing in a bucolic setting in the early morning sunlight, intently working but at peace. Our second figure is, of course, Gregor Mendel (1822-1884), popularly regarded as the pioneer of genetics and-according to the sample textbook open before us (Sadava et al. 2011) - the scientist who disproved the venerable, long-standing canard of trait blending or blending inheritance.

Mendel is a known historical figure precisely because he was supposedly the first to envision how we moderns understand inheritance. Trained first in physics, he imported into biology an appreciation for mathematical order and natural laws. He is said to have formulated two laws of his own: the first is that alleles of the same gene appear in pairs in individuals and segregate in gamete production; the second is that the alleles of different genes sort independently. He predicted that two forms of the same trait sort in a 3-to-1 ratio in the first generation, whereas two forms of two different trait sort in 9-to-3-to-3-to-1 ratio in a second generation. Mendel learned this because he formulated a detailed research agenda and took pains to follow it through precisely, attacking the mysteries of trait segregation for 8 years, hundreds of crosses, thousands of progeny.

Mendel presented the findings of this extensive research at the Natural History Society of Brünn, then in Austria (now Brno, Czech Republic) in February and March 1865 and then distributed copies of his paper to significant individuals across Europe and to

E. L. Peterson

University of Alabama, Tuscaloosa, AL, USA

e-mail: elpeterson@as.ua.edu

K. Kampourakis $(\bowtie)$

University of Geneva, Geneva, Switzerland

e-mail: Kostas.Kampourakis@unige.ch 
naturalist societies outside Austria. ${ }^{1}$ In ten letters written from 1866 to 1873 , he appealed to Swiss botanist Carl Wilhelm von Nägeli, Extraordinary Professor at the University of Munich, in an attempt to clarify and defend his concepts. Nägeli acknowledged Mendel's experimental skill, but when he published his own Mechanisch-physiologische Theorie der Abstammungslehre (Mechanical-physiological Theory of the Descent Doctrine, 1884), a work that could have mentioned Mendel's Pisum experiments, he did not. Mendel's important work was effectively ignored during his lifetime. Only in 1900, after Carl Correns, Hugo De Vries, and Erich Tschermak uncovered Mendel's findings-and after Cambridge's William Bateson rendered Mendel's work into a defensible theory-were scientists able to appreciate the fundamental genius of his work. Sixteen years after Mendel's death, and over three decades after his groundbreaking research, the field of genetics was born.

That is the "scientist in monk's clothing" received story. It can be found repeated in biology textbooks, on websites, in popular scientific literature, and even printed on t-shirts. And it persists, although ever since the last Mendel memorial in 1965, historians of science have challenged nearly every word of it.

Questioning the received story actually began in 1936, three decades before the first Mendel memorial. Ronald A. Fisher, founding member of the 1930s neo-Darwinian Synthesis, argued that the statistical ratios attached to Mendel's name were too good to be strictly inductive. The obvious implications were either that Mendel forged the results or that he deliberately or accidentally selected a species, his famous peas, that would breed along the sharp lines he wanted to find. During the first centenary period in the 1960s, another neo-Darwinian pillar, Theodosius Dobzhansky, came to Mendel's aid. The Russian geneticist admitted that the tendency to disregard a potentially falsifying result as a mistake if it cannot be made to fit with expectations is a natural one for any scientist, no matter how orthodox: "Not having been familiar with Chi squares and other statistical tests, Mendel may have, in perfect conscience, thrown out some crosses which he suspected to involve pollen contamination or other accident." Of course with that statement-printed in a prominent review of six contemporary Mendel studies, two focused on the centenary itself-Dobzhansky implicitly conceded that Mendel's data really were so clean that they must have been manipulated; perhaps understandable when we recall that Mendel was "not a professional scientist" (Dobzhansky 1967, p. 1588).

While these early challenges focused on Mendel's math and his presentation of data, Olby (1979) disputed the received view's depiction of Mendel's philosophy. The Mendel belonging to the received story "subscribe[d] explicitly to the existence of a finite number of hereditary elements which in the simplest case is two per hereditary trait, only one of which may enter a germ cell....". The real Mendel, charged Olby, was no Mendelian in this sense. Once denuded "of inflated whiggish interpretations" and properly contextualized in the mid-nineteenth-century Central European horticulturalist milieu, Mendel appears brilliant but metaphysically typical (Olby 1979, pp. 53, 68). He wasn't elucidating the reductionistic philosophy that would underwrite the tacit preformationism of "genesfor" language in the neo-Darwinian Synthesis 70 years too early. Instead, suggested Olby, Mendel addressed quite a different puzzle-How does hybridization contribute to

\footnotetext{
1 The full citation of Mendel's famous paper is: Mendel Gregor 'Versuche Über Pflanzen-Hybriden'. Verhandlungen Des Naturforschenden Vereines Zu Brünn 4 (1866): 3-47. The most recent, authoritative translation of Mendel's paper is the one by Kersten Hall and Staffan Müller-Wille and it can be accessed at: http://www.leeds.ac.uk/heritage/Mendel/index.html.
} 
speciation?-which required nothing resembling the invisible, particulate gene theory now highlighted in textbooks.

In the same year, 1979, Augustine Brannigan argued that, although Mendel was working in the older tradition of hybridists, "Versuche" was co-opted to resolve a more modern priority dispute between Hugo de Vries and Carl Correns. De Vries published two papers in 1900, both reporting 3-to-1, i.e., "Mendelian," ratios. Mendel's name only appeared in the second paper, however. Having read the first paper, and having recognized the ratios from Mendel's work, Correns-who was Nägeli's student-wrote a paper detailing the discovery of 'Mendel's Rule'. Correns thus emphasized Mendel's priority over both de Vries and himself (Brannigan 1979). According to Brannigan, it was this dispute that potentially reintroduced Mendel to botanists at the turn of the twentieth century.

More recent historians have even questioned the fundamental reason to include Mendel's story into a textbook in the first place: the singularity of his discovery. As Kampourakis (2013) emphasizes, the late Victorian period saw contributions to the study of heredity from a broad, international community of scholars who read each others' works, including Charles Darwin, Herbert Spencer, Francis Galton, William Keith Brooks, Carl Nägeli, August Weismann, and Hugo de Vries. William Bateson was working on his own theory of trait segregation and transmission in the 1890s, which made him especially capable of promoting Mendelism to the Anglo-American world. Therefore to extoll Mendel alone and ignore the communal aspect of the nineteenth-century study of heredity is to distort not only the historical record but to idealize a process of scientific discovery-the isolated genius - actually opposed to the one we wish to promote in our classrooms-the scientific community. The received view begins to look more like hagiography than history.

With all of these marks against the received view, why, then, does it persist? In the middle of the last century, Herbert Butterfield and Thomas Kuhn hinted at why this sort of history of science is insufficient - and why it is told and retold nonetheless. They would have agreed, of course, that histories of science, like all histories, could not be unfettered, unbiased chronicles of events. But admitting the potential taint of bias is not the same thing as capitulating to thorough-going relativism; one can adjudicate better and worse histories even if one cannot offer entirely impartial accounts. One shortcoming of textbook-friendly history of science is that it often plays the role of obedient arts and humanities handmaiden, dressing up trial-and-error, pragmatic scientific practice with the elegance of logical hindsight. Butterfield witnessed this style of history and criticized the distortions it produced over the long term:

[T] he whole fabric of our history of science is lifeless and its whole shape is distorted if we seize upon this particular man ... who had an idea that strikes us modern, now upon another man... who had a hunch or an anticipation of some later theory.... It has proved almost more useful to learn something of the misfires and the mistaken hypotheses....

[I]t is necessary not merely to describe and expound discoveries, but to probe more deeply into historical processes and to learn something of the interconnectedness of events, as well as to exert all our endeavors for the understanding of men who were not like-minded with ourselves. (Butterfield 1957, pp. 8-9).

Thomas Kuhn went beyond Butterfield, directly cross-examining the history of science ensconced in textbooks. Histories of science are not merely filler or window dressing, a diversion from doing real science. Histories serve a crucial purpose: to justify paradigms. 
Revolutions close with a total victory for one of the two opposing camps. Will that group ever say that the result of its victory has been something less than progress? ... To them, at least, the outcome of revolution must be progress, and they are in an excellent position to make certain that future members of their community will see past history in the same way....When it repudiates a past paradigm, a scientific community simultaneously renounces, as a fit subject for professional scrutiny, most of the books and articles in which that paradigm had been embodied. Scientific education makes use of no equivalent for the art museum or the library of classics, and the result is a sometimes drastic distortion in the scientist's perception of his discipline's past. ... [H]e comes to see it as leading in a straight line to the discipline's present vantage. (Kuhn 1996, pp. 166-167).

So if we accept the characterizations of Butterfield and Kuhn, then the history of science that appears in textbooks serves a purpose in addition to-perhaps even instead offaithfulness to an exact rendering of what happened: supporting a paradigm.

What paradigm could this mythological textbook account of Mendel be supporting? Early in the twentieth century, philosopher of mathematics Alfred North Whitehead (1953) identified the paradigm that set the stage for the rise of Mendel-ism. He called it Democritean-Cartesianism. When applied to biology, the Democritean-Cartesian perspective had four principle features, the first three of which were: (a) the extension of scientific analysis into the territory of inheritance, which had once been the explanatory domain of other social spheres, including religion, (b) the reorientation of biological explanations away from processes, fluids, humors, fields, and other imprecise notions and toward the structures and behaviors of aggregating particles, and (c) the extension of quantitative concepts into biology. Indeed, without recognizing Whitehead, Russian biophysicist Nikolay V. Timofeev-Ressovsky defended these reasons for celebrating Mendel's legacy during the centennial a half-century ago:

[Mendel] became the pioneer in introducing strict mathematical thought into biology and founded the basis for...genetics in our century; and we may state now that genetics together with evolution theory, grounded on the principles of selection, is the basis upon which the biological thought is to be formed, and which imparts the powerful stimulus for the development of all fields of modern biology.

(Timofeev-Ressovsky 1966, p. 47).

In other words, according to Timofeev-Ressovsky's version of it, the Mendel myth supported an ever-expanding scientific magisterium driven by the need to account for the structure and behavior of discrete particles rather than whole organisms, and only considered "scientific" when biological phenomena became quantifiable. Without recognizing that they are doing so, those who promote the Mendel myth end up also promoting the Democritean-Cartesian worldview.

Whitehead also pointed to a fourth way the Democritean-Cartesian worldview impacted biology: (d) it promised greater control of the biological world. This, certainly, was what some of the early Mendelians and their eugenicist compatriots promoted. Sure enough, that meta-narrative continues to ring true: turning again to our sample modern biology textbook (Sadava et al. 2011), the Mendel story introducing the mid-twentieth century gene concept flows into a section exploring the promises of contemporary biotechnology to improve society, cure disease, and so on.

Is this, then, why Science \& Education is dedicating a thematic issue to Mendel? Is this issue another addition to a history of Mendel supporting the larger Democritean-Cartesian worldview tacitly replicated in biology textbooks? It is not. Are we perhaps in pursuit of an opposing agenda, then-promoting essays that attack Mendel's legacy? No, this issue is not a concerted attack on Mendel historiography, a denigration of Mendel's work, or a dismissal of post-1900 Mendelism. The value of the essays assembled here is that they transcend either of these limited goals. Without question, they complicate the history of the man, his discoveries, the context of their justification, and the history of Mendelism itself. 
In so doing, however, they affirm the stature of his achievement, the influence of the science that followed from it, and the need for more-not less-Mendel to appear in the science classroom, but with different pedagogical aims.

Most importantly, given the myths and the distortion of history one usually finds in popular accounts of Mendel, it is important to provide a more accurate and richer view of history. This is why most of the articles in this thematic issue are contributions made by expert historians on various less-well known aspects of this history, in an attempt to provide a more informed view of it. Moreover, three articles focus on the presentation of Mendel in educational material and highlight what has been done so far and what more could be done.

\section{Overview of the Contents of the Thematic Issue}

The collection begins with the essay by Vítězslav Orel and Margaret H. Peaslee, scholars who richly narrate the long arc of Mendel's contribution and specific moments of tension regarding the reading of that contribution. Orel and Peaslee frame Mendel's work as the completion, through many twists and turns, of an educational program launched in the early seventieth century by theological and educational reformer Jan Amos Comenius. They then turn to the twin historiographical debates mentioned above: Mendel's "too good" data and Mendel's status as discoverer of modern genetics. While sidestepping anything like the textbook story of Mendel, the authors defend the thesis that Mendel's contributions were greater than the sum of the parts he borrowed from earlier scholars and certainly worthy of special mention. Mendel's work was indeed paradigmatic-in the original Kuhnian sense of that term. ${ }^{2}$

Ida Stamhuis, Hans-Jörg Rheinberger, Nicolas Gillham, and Garland Allen revisit the legacies of four early interpreters of genetics in, respectively, the Netherlands, Germany, the UK, and the USA. As they demonstrate, we need to reconceptualize not only Mendel's role, but also the roles of those who forged an -ism from Mendel's work. Why, for instance, did De Vries end up working against orthodox Mendelism after his early recognition of it? Why did Thomas H. Morgan, who like De Vries had his own thoughts about heredity, end up reversing his earlier theories-not once but three times? How did Morgan manage to convince even English scion of genetics William Bateson about the material nature of chromosomes while both figures remained only instrumentally committed to a hardened gene concept? Why have we learned so little about Carl Correns' work though, as Rheinberger shows, the work of this German geneticist not only initiated the first major recognition of Mendel in 1900, but also developed by the 1920s into an appreciation for non-nuclear influences on inheritance? And how is it possible that Francis Galton's work in the last quarter of the nineteenth century inspired both Mendelism and the Biometricians' challenge to it in the first decades of the twentieth century? These four essays offer new portals into these questions.

Margaret Peacock's contribution "Mendel Lives" wrestles with one of the most pervasive tropes in the history of twentieth century science: To what extent did Lysenkoism extinguish the teaching of Mendelism within the Soviet Union? Early Cold War accounts,

\footnotetext{
2 As many readers no doubt know, for decades Orel has sparred in the historical literature with Robert Olby. We hoped to have Olby contribute an article continuing the dialog with Orel and Peaslee in this issue. Regretfully, though he expressed his desire to do so, it was not possible to include Olby's valuable contribution to this thematic issue.
} 
such as Julian Huxley's Heredity East and West (1949, p. 151) claimed that in the "Totalitarian Regimentation of Thought" of Stalin's regime snuffed out true biologyclassically represented by Mendelism. More recent scholarship, including Roll-Hansen's definitive Lysenko Effect (2005, p. 282) tones down the rhetoric but reinforces the point that "poor science [drove] out the good." But Peacock's penetrating research into texts available to students throughout the USSR suggests not that Lysenko or Lysenkoism had some other effect, but that "totalitarian regimentation" better describes the intellectual landscape near the core of biological research. If we refocused our historical lenses at the periphery, we would find teachers and students still learning about Mendel's science well after the ascent of Lysenko. The greater lesson that Peacock's article seems to demonstrate is that top-down mandates regarding scientific knowledge are often difficult to implement-they encounter infra-political resistance, to co-opt James C. Scott's term (1990, p. 183).

Ron Numbers' article presents the flip-side of Peacock's positive message. Whereas Peacock demonstrates the persistence of a subaltern Mendel flying beneath the radar of Soviet Lysenkoism, Numbers' Mendel is used as creationist shill by fundamentalist Christians in the USA. Here Numbers invites us to explore agnotology - the active creation of ignorance (Proctor 2008). In this case, the convenient deployment of Mendelian leaps or saltations provides scientific cover for the denial of the dominant interpretation of evolution as gradualistic, blind, and selection-based. Instead, Mendelism becomes a backdoor for anti-evolutionary accounts that depict life as ordered, not chaotic, and therefore designed. This use of Mendel is not a historically accurate position with the discrete, century-long internal debates about the mode and tempo of evolution but an attempted disproof of Evolutionary Theory as a whole. But that matters little because, as Numbers signals, anti-evolutionists locate their disproof in a work of the staunchest Mendelian: William Bateson's "Evolutionary Faith and Modern Doubts” (1922).

But Bateson can be written as a hero as well as a quasi-villain. Marsha Richmond explores this side of Bateson as by-turns patriarch and mentor to young women chiseling their way into the world of modern science. While Bateson's role was no doubt complicated, Richmond shows how under his direction at John Innes Horticultural Institute women were able to participate in interdisciplinary, cutting-edge work. Two other men better known for their pursuit of the social implications of their Mendelism, Charles Davenport in the USA and Edwin Baur in Germany, followed Bateson's lead, opening a space for women to conduct scientific research outside of the university. Many women did successfully exploit the opening; some, like Edith Saunders, extended Mendelism far beyond where their male counterparts could have taken the field.

The thematic issue's final three articles by Mike U. Smith and Niklas Gericke, Charbel El Hani, and Megan F. Campanile, Norman G. Lederman, and Kostas Kampourakis demonstrate that what we understand about the history and philosophy of Mendel and Mendelism matters in the classroom and, therefore, to what a future public will believe about Mendel, genetics, and the nature of science more broadly.

After rehearsing the contentious Mendel historiography, including a much more detailed rendering of the scientist-in-monk's-robes textbook account than the one sketched above, Smith and Gericke suggest that the continued use of Mendel in the classroom is warranted-as long as it can be stripped of the century and a half of misunderstandings attached to the account.

El Hani extends the critique of mythological Mendel into journals dedicated to training pre-service teachers and the education school professors who sculpt those teachers. Though there are some promising exceptions, for the most part academic journals directed at 
educators repeat the anachronistic myth and even harden it-Mendel not only as father of genetics but as the lion-tamer of unruly biology using scientific methods previously unknown.

Finally, Campanile, Lederman, and Kampourakis complete this exploration by carefully examining the deployment of the Mendel myth in textbooks. They pay special attention to those portions in textbooks that purport to teach the nature of science and scientific inquiry. Unsurprisingly, they discover that conversations regarding the nature of science and scientific inquiry appear repeatedly in those segments of textbooks devoted to teaching Mendelian genetics. So the students are receiving information about scientific inquiry and the nature of science along with their genetics! However, the authors stress that this information is in most cases implicit and so it is likely to be overlooked. Perhaps, they suggest, it would be more efficient to address how to interpret and properly employ textbooks in the classroom rather than "fix" the texts themselves.

\section{Conclusions}

Collectively, these articles address another looming question, especially given the potential criticisms mentioned above: Why bother celebrating Mendel and "Versuche über Pflantzen-Hybriden" in the first place? Why look backwards to commemorate? Charles Maier highlighted the tension in our collective task here:

Commemoration involves the invocation and nurturing of solidarity; history requires the undermining and questioning of solidarities. At the same time, the historical impulse cannot be liberated from the commemorative. It is illusory to expect that modern science, the adventure par excellence of the twentieth century, can escape that tension. (Maier 1999, p. xii).

The reader will have to judge whether this issue holds up under the tension Maier identifies between commemoration and history-both building up and tearing down solidarities. We believe it does insofar as these authors admit, even while contesting it, the power of the Mendelian metonym - i.e., that scientist-in-monk's-robes story and the metaphysics and sociology of science that follows from it. We believe all would admit that the metonym had and continues to have an unparalleled impact upon modern biology in the laboratory and the classroom.

Gregor Mendel, the Augustinian friar (he was not a monk, actually!) indeed had an impact after 1900 when his work was read in a scientific and philosophical context that had changed significantly in the four decades since his original work. Mendel's own work was conducted in the tradition of hybridists-assuredly not research that aimed to "discover" how heredity takes place. However, when "Versuche" was read in the context of the new framework of hardened heredity following Galton, Weismann, and the late nineteenthcentury discoveries of cell division, it was recast as the foundational document of genetics. Mendel's painstaking experimental approach, elegant mathematical formalization, and implicit determinism resonated with the biology of the new century. But it also made Mendel an immensely mythical figure. We hope that this issue contributes to a more thoughtful distillation of the historical record and, by doing so, assists educators in segregating the human history of science from scientific hagiography.

\section{References}

Brannigan, A. (1979). The reification of Mendel. Social Studies of Science, 9, 423-454.

Butterfield, H. (1957). The origins of modern science, 1300-1800 (Revised ed.). New York: The Free Press. Dobzhansky, T. (1967). Looking back at Mendel's discovery. Science, 156, 1588-1589.

Fisher, R. A. (1936). Has Mendel's work been rediscovered? Annals of Science, 1, 115-137. 
Huxley, J. (1949). Heredity, East and West: Lysenko and World Science. New York: Schuman.

Kampourakis, K. (2013). Mendel and the path to genetics: portraying science as a social process. Science \& Education, 22(2), 293-324.

Kuhn, T. S. (1996). The structure of scientific revolutions (2nd ed.). Chicago, IL: University of Chicago Press.

Maier, C. S. (1999). Commemorative practices in science: historical perspectives on the politics of collective memory-Preface. Osiris, 14: ix-xii.

Olby, R. (1979). Mendel, no Mendelian?". History of Science, 17, 53-72.

Proctor, R. N. (2008). A missing term to describe the cultural production of ignorance (and its study)". In Robert N. Proctor \& Londa Schiebinger (Eds.), Agnotology: the making \& unmaking of ignorance (pp. 1-33). Palo Alto, CA: Stanford University Press.

Roll-Hansen, N. (2005). The lysenko effect: the politics of science. Amherst, NY: Humanity Books.

Sadava, D., Hillis, D. M., Heller, H. C., \& Berenbaum, M. R. (2011). Life: the science of biology. Sunderland, MA: Sinauer Associates Inc.

Scott, J. C. (1990). Dominance and the arts of resistance: hidden transcripts. New Haven: Yale University Press.

Whitehead, A. N. (1953). Science and the modern world (Lowell Lectures, 1925). New York: Free Press. 